\title{
PENGARUH HASIL TANGKAPAN ALAT TANGKAP BUBU DASAR DENGAN MENGGUNAKAN UMPAN YANG BERBEDA DI SUNGAI TEMBESI KABUPATEN MERANGIN PROVINSI JAMBI
}

\author{
Meiki Jeksen*, Syafrialdi**, Djunaidi** \\ * Alumni Jurusan Pemanfaatan Sumber Daya Perikanan Fakultas Perikanan UMB \\ **Fakultas Perikanan Universitas Muara Bungo
}

\begin{abstract}
ABSTRAK
Sungai Tembesi adalah Sungai yang terdapat di Kecamatan Jangkat, disepanjang aliran Sungai Tembesi terdapat aktivitas masyarakat seperti pemukiman penduduk, persawahan dan areal perkebunan, selain itu Sungai Tembesi merupakan salah satu sarana penerangan melalui pembangkit listrik tenaga air dan juga dimanfaatkan oleh masyarakat petani nelayan untuk usaha atau aktivitas penangkapan ikan. Salah satu alat tangkap yang banyak digunakan sebagai alat penangkapan di Sungai Tembesi adalah Bubu dasar. Keberhasilan penangkapan menggunakan bubu dipengaruhi oleh beberapa faktor salah satunya adalah umpan.

Penelitian ini dilaksanakan di Sungai Tembesi Kabupaten Merangin Provinsi Jambi yang di mulai dari tanggal 03 Oktober 2018 sampai 21 Maret 2018. Penelitian ini bertujuan untuk mengetahui pengaruh jenis umpan berbeda terhadap jenis ikan yang tertangkap, jenis umpan yang paling disukai oleh ikan serta untuk mengetahui jenis hasil tangkapan dengan menggunakan umpan yang berbeda pada alat tangkap bubu dasar.

Metode yang digunakan dalam penelitian ini adalah metode observasi lansung ke lapangan dan metode penentuan stasiun sampel dilakukan dengan cara Purpoisive sampling sedangkan analisis data menggunakan Rancangan Acak Kelompok (RAK) dengan 5 Kelompok dan 3 perlakuan umpan yang berbeda yaitu dedak halus, jagung dan ubi. Parameter yang diamati adalah pengaruh perbedaan umpan terhadap jumlah total ikan (ekor) dan berat total ikan (gram) hasil tangkapan serta jenis ikan yang tertangkap di Sungai Tembesi dengan alat tangkap bubu dasar yang dioperasikan sebanyak 3 unit.

Hasil penelitian menunjukan bahwa jenis umpan yang berbeda berpengaruh nyata terhadap berat total (gram) ikan dan jumlah total (ekor) ikan yang tertangkap bubu dasar di Sungai Tembesi Kabupaten Merangin (F hitung > F tabel) dan dedak halus merupakan umpan yang disukai ikan yang tertangkap dengan menggunakanan alat tangkap bubu dasar di Sungai Tembesi Kabupaten Merangin. Hasil tangkapan menggunakan bubu dengan umpan yang berbeda menghasilkan sebanyak 3 jenis ikan yaitu Semah, Pareh dan Seluang
\end{abstract}

\section{Kata Kunci : Umpan, Dedak Halus, Bubu Dasar dan Hasil Tangkapan}

\section{PENDAHULUAN}

Perikanan di Indonesia terbagi secara ekologis dalam beberapa area yaitu: perikanan laut, perikanan air tawar dan perikanan pantai. Perikanan air tawar terdiri dari kegiatan budidaya dan penangkapan ikan di perairan umum (DAS, danau dan waduk). Perairan umum adalah bagian dari permukaan 
bumi yang secara permanen atau berkala digenangi air, baik air tawar maupun air laut, mulai dari garis pasang surut laut terendah ke arah daratan dan badan air tersebut terbentuk secara alami atau buatan. Menurut Budiyono (2011), Perairan umum terdiri dari danau, waduk, rawa, lebak, sungai serta genangan lainnya merupakan salah satu sumberdaya perairan yang potensial untuk dikembangkan dalam memenuhi kebutuhan protein bagi masyarakat, seperti kegiatan penangkapan dan budidaya perikanan

Berdasarkan data BPS Merangin (2015), bahwa perairan umum di Kabupaten Merangin dengan luas $4.548 \mathrm{Ha}$ yang terdiri dari perairan Rawa, Danau, Dam, dan Sungai. Diantara beberapa sungai yang ada di Kabupaten Merangin antara lain adalah Sungai Tembesi, Sungai Batang Panggi, Sungai Batang Langganyo, Sungai Batang Mareh, Sungai Tabir, Batang Merangin, Batang Telentam, Batang Mesumai dan Sungai Menyabu.

Sungai Tembesi adalah sungai yang terdapat di Kecamatan Jangkat, berdasarkan hasil observasi di lapangan bahwa disepanjang aliran Sungai Tembesi terdapat aktivitas masyarakat seperti pemukiman penduduk, persawahan dan areal perkebunan. Selain itu Sungai Tembesi merupakan salah satu sarana penerangan melalui pembangkit listrik tenaga air dan juga dimanfaatkan oleh masyarakat petani nelayan untuk usaha atau aktivitas penangkapan ikan. Berbagai aktivitas penangkapan ikan telah dilakukan oleh para nelayan yang tinggal kawasan sungai ini, alat tangkap yang digunakan umumnya mereka rancang sendiri berdasarkan pengalaman serta hambatan yang ditemui saat operasi penangkapan ikan. Alat tangkap bubu dasar saat ini, banyak digunakan sebagai alat penangkapan di Sungai Tembesi. Berdasarkan wawancara dengan masyarakat di Sungai Tembesi, penangkapan ikan yang dilakukan adalah usaha sampingan sedangkan usaha utama adalah sebagai petani dengan kebiasaan pemasangan bubu dilakukan saat pulang dari kebun dan keesokan hari dilakukan pengangkatan atau hauling. Adapun masyarakat yang memiliki bubu adalah sebanyak \pm 12 orang dengan umpan yang sering digunakan adalah dedak halus.

Jenis Bubu merupakan alat tangkap yang termasuk ke dalam kelompok alat tangkap pasif. Bubu ini digunakan untuk ikan yang berada di dasar (demersal). Bubu mempunyai ukuran yang bervariasi tergantung kebutuhan nelayan. Menurut Subani dan Barus (1989) ukuran bubu yang di operasikan di perairan Indonesia pada umumnya dibagi pada 3 ukuran yaitu ukuran kecil, sedang dan besar.

Keberhasilan penangkapan menggunakan bubu dipengaruhi oleh beberapa faktor antara lain konstruksi bubu, lama perendaman (soaking time) dan umpan (Miler, 1990 dalam Watem $d k k$, 2015). Hal ini diperkuat Subani dan Barus (1989) bahwa keberhasilan suatu operasi penangkapan ikan, khususnya untuk alat tangkap pasif seperti bubu dan pancing sangat ditentukan oleh umpan yang tepat.

Penelitian bertujuan untuk mengetahui pengaruh jenis umpan berbeda, jenis umpan yang terbaik serta jenis hasil tangkapan menggunakan umpan yang berbeda pada alat tangkap bubu dasar

Penelitian terhadap alat tangkap bubu dasar menggunakan umpan berbeda pada penelitian ini penting dilakukan untuk mengetahui apakah ada perbedaan hasil tangkapan dari perlakuan berbeda sehingga kajian mengenai umpan yang berbeda pada bubu perlu dilakukan untuk efektifitas pada alat tangkapan.

\section{METODE PENELITIAN}

Penelitian ini dilakukan di Sungai Tembesi Kecamatan Jangkat Kabupaten Merangin dengan lokasi (1) Lubuk Tulang Desa Ranta Suli, (2) Lubuk DAM PLTA Desa Rantau Suli (3) Lubuk Batu Desa Rantau Suli, dan penelitian ini dilaksanakan dari bulan Oktober sampai bulan Maret 2018. Peta lokasi penelitian dapat dilihat pada Gambar 1 . 
SEMAH : Journal Pengelolaan Sumberdaya Perairan

VOL. 2 No. 2

Desember 2018

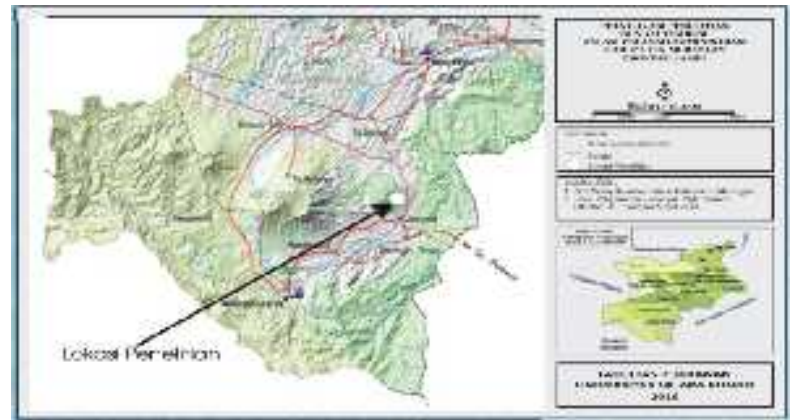

Gambar 1. Peta Lokasi Penelitian

Peralatan yang digunakan untuk penelitian ini yaitu : alat tangkap bubu dasar sebanyak 3 unit, kaca mata selam, kamera digital, alat tulis, timbangan elektrik dan lain sebagainya.

Sedangkan bahan yang digunakan pada penelitian berupa umpan yaitu dedak halus, jagung, ubi, pasir dan tanah liat. Untuk pengumpulan data digunakan data primer dengan cara observasi langsung kelapangan dan data sekunder diambil dari instansi yang terkait seperti dinas perikanan, dinas statistik dan kecamatan serta literatur-literatur yang berhubungan dengan penelitian ini. Ikan yang tertangkap didentifikasi di laboratorium Universitas Muara Bungo.

Metode penentuan stasiun pengambilan sampel dilakukan dengan cara purposive sampling dimana penentuan dimana penentuan stasiun dengan pengamatan sesuai dengan kondisi tempat penelitian. Adapun deskripsi masing-masing Stasiun yaitu Stasiun I berada dekat lubuk yang mempunyai kedalaman 173 $\mathrm{cm}$ dan lebar 7 - $8 \mathrm{~m}$ yang ditandai dengan adanya jembatan dan tempat pemandian, serta kiri dan kanan sungai terdapat persawahan warga dengan jarak antar stasiun II $\pm 5 \mathrm{Km}$, Stasiun III berjarak $\pm 5 \mathrm{Km}$. Dengan titik koordinat $2^{0} 33^{\prime} 41^{\prime \prime}$ LS dan 101 ${ }^{0} 58^{\prime} 10$ 'BT.

Stasiun II berada di sekitar PLTA atau DAM PLTA dengan kedalaman $192 \mathrm{~cm}$ dan lebar sungai 9 meter dan berjarak $\pm 5 \mathrm{Km}$ dari stasiun I dan dan $\pm 5 \mathrm{~km}$ dari stasiun III. Dengan titik koordinat 2033'26" LS dan $101^{0} 58$ '27'BT. Stasiun III berada di wilayah
ojs.umb-bungo.ac.id/index-php/SEMAHJPSP

ISSN : 2580-0736

pertanian atau persawahan masyarakat, stasiun ini mempunyai kedalaman $165 \mathrm{~cm}$ dan lebar sungai 6-7 meter dengan jarak antar stasiun \pm 5 $\mathrm{Km}$. Dengan titik koordinat $2^{0} 33^{\prime} 14^{\prime \prime}$ LS dan $101^{0} 59^{\prime} 8^{\prime \prime} B T$.

Bubu yang digunakan selama penelitian berjumlah 3 unit yang terbuat dari bahan material alami, yaitu bambu dengan ukuran injab depan $30 \mathrm{~cm}$ dan panjang $80 \mathrm{~cm}$. Bubu ini berbentuk kerucut yang memiliki dua buah injab (mulut), dimana injab pertama berfungsi sebagai pintu masuk. Bentuk mulut atau injab bulat seperti corong yang semakin kedalam semakin kecil dengan prinsip agar ikan yang telah masuk ke dalam bubu tidak dapat keluar. Injab kedua hanya sebagai pembatas badan belakang dan badan depan dengan tujuan agar ikan tidak leluasa bergerak dan dapat menambah kekuatan bubu. Badan bubu bagian belakang berfungsi sebagai tempat meletakkan umpan selain tempat ikan terkurung. Badan belakang memiliki pintu yang berfungsi sebagai tempat memasukkan umpan sedangkan tempat mengeluarkan hasil tangkapan berada di depan yang ditutup dengan bato kelapa. Bubu dioperasikan dengan cara meletakan di dasar sungai di bagian pinggir atau tebing sungai pada kedalaman air 50-150 cm. Bubu diletakan dengan bagian depan bubu diarahkan menghadap ke hilir sungai. Agar tidak terbawa arus air maka bubu diberi pemberat berupa batu. Masingmasing bubu dilengkapi tiga pemberat dan dua pelampung. Pemberat diletakkan di bagian depan, tengah dan dibelakang Pelampung yang digunakan adalah bambu dan kayu yang langsung diikat pada bubu berfungsi sebagai tanda. Bubu dioperasikan dengan cara diberi umpan berupa (1) Dedak halus yang dicampur pasir, (2) Jagung dan (3) Ubi. Umpan diletakan pada bagian belakang (penutup) bubu yaitu diletakan di dalam batok kelapa. Ikan yang tertangkap dikeluarkan melalui penutup di bagian depan bubu. Bubu dasar dioperasikan pada malam hari, pemasangan (setting) dilakukan secara serentak pada lokasi yang telah ditentukan pada Jam $16 .{ }^{00}$ WIB (sore hari) dan diangkat (hauling) pada 
keesokan hari yaitu jam 16. ${ }^{00}$ WIB. Ikan yang diperoleh kemudian dipisahkan berdasarkan umpan yang telah dipasang dimana ikan tersebut tertangkap.

Data yang dikumpulkan meliputi jenis ikan dan berat ikan, jumlah jenis ikan, pemasangan alat tangkap dan pengangkatannya, kedalaman perairan, dan jenis umpan. Data jenis ikan yang tertangkap dengan menggunakan bubu dengan umpan yang berbeda selanjutnya diidentifikasikan menggunakan kottelat, et al., 1993 dan saanin, 1984 dan ditimbang beratnya setiap perlakuan dengan menggunakan timbangan ketelitian 0,1 g kemudian dilanjutkan dengan tabulasikan data.

Rancangan yang di gunakan dalam penelitian ini adalah Rancangan Acak Kelompok (RAK) dengan 5 Kelompok dan 3 perlakuan umpan yang berbeda yaitu dedak halus, jagung dan ubi. Asumsi dasar untuk percobaan dengan rancangan acak lengkap adalah hasil pengamatan Xij dapat dituliskan dengan model aditif sebagai berikut :

Model linier yang tepat untuk rancangan acak kelompok adalah:

$$
\mathbf{Y i j}=\boldsymbol{\mu}+\boldsymbol{\alpha} \mathbf{i}+\boldsymbol{\beta} \mathbf{j}+\mathbf{\varepsilon} \mathbf{j}
$$

dimana:

$$
\mathrm{i}=1,2, \ldots \mathrm{n} ; \text { dan } \mathrm{t}=1,2, \ldots \mathrm{n}
$$

$\mathrm{Yi}(\mathrm{t})=$ nilai tengah pengamatan dari kelompok ke-j, yang memperoleh perlakuan ke-i.

$\mu \quad=$ nilai tengah populasi

$\boldsymbol{\alpha} \mathbf{i}=$ pengaruh perlakuan ke-i

$\boldsymbol{\beta} \mathbf{j}=$ pengaruh kelompok ke-j

$\mathrm{ei}(\mathrm{t})=$ Galat dari kelompok ke-j yg memperoleh perlakuan ke-i

Data yang didapat dianalisis guna mengetahui keragaman data yang diperoleh dilakukan analisis Sidik Ragam (Anova) dengan tingkat kepercayaan 99\%. Apabila F hitung < F tabel maka $\mathrm{H} 0$ diterima dan $\mathrm{H} 1$ ditolak yang berarti tidak ada pengaruh jenis umpan terhadap hasil tangkapan ikan dan apabila $\mathrm{F}$ hitung > F tabel maka $\mathrm{H} 0$ ditolak dan $\mathrm{H} 1$ diterima sehingga ada pengaruh jenis umpan terhadap hasil tangkapan ikan. Ikan yang tertangkap dengan umpan yang berbeda diamati ukuran berat total ikan serta diamati jenis ikan. Kisaran berat total ikan pada masing-masing umpan dibandingkan satu dengan lainnya untuk mengetahui perbandingan variasi ukuran ikan yang tertangkap. Untuk mengetahui hasil tangkapan ikan maka ikan hasil tangkapan dipisahkan, dicatat dan ditabulasikan berdasarkan jenis umpan. Total hasil tangkapan dihitung dari penjumlahan data hasil tangkapan/ perlakuan/lokasi.

\section{HASIL DAN PEMBAHASAN}

\section{A. Pengaruh Hasil Tangkapan dengan Umpan yang Berbeda \\ 1. Jumlah Total (Ekor) Ikan}

Hasil penelitian menunjukan bahwa jumlah total (ekor) ikan yang tertangkap menggunakan Bubu Dasar di Sungai Tembesi pada umpan yang berbeda setiap stasiun dapat digambarkan pada pada Gambar 2

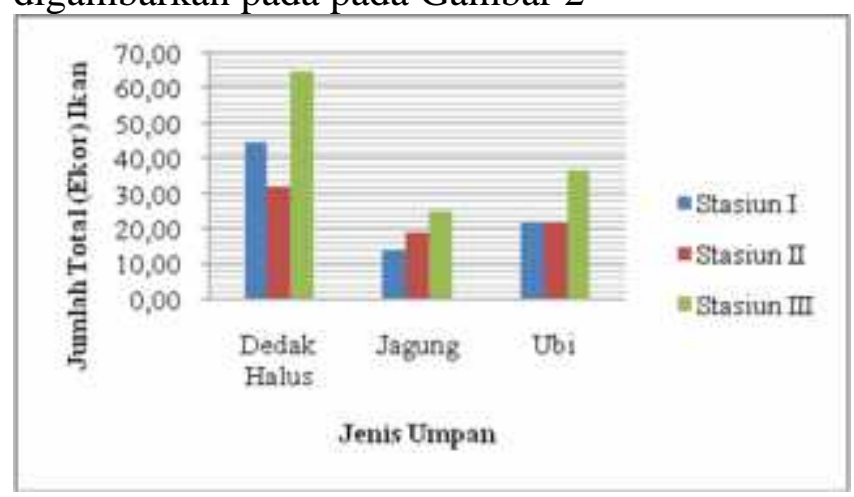

Gambar 2. Histogram Jumlah Total (Ekor) Ikan

Gambar 2 menunjukan bahwa hasil tangkapan Bubu Dasar yang dilakukan dengan mengunakan umpan dedak halus merupakan umpan yang paling banyak menangkap ikan. pada setiap stasiun selama penelitian. Untuk melihat pengaruh umpan berbeda terhadap jumlah total (ekor) ikan yang tertangkap dilakukan analisis ragam anova dengan rancangan acak kelompok (RAK). Hasil analisis ragam menunjukan bahwa perlakuan 
umpan yang berbeda berpengaruh sangat nyata terhadap jumlah total (ekor) ikan yang tertangkap Bubu Dasar $(\mathrm{P}<0,01)$. Untuk melihat umpan mana yang paling baik terhadap jumlah ikan yang tertangkap maka dilanjutkan dengan uji jarak Berganda Duncan Multipe Range Test (DMRT) pada taraf $5 \%$ (Steel and Torrie, 1994). Adapun rataan jumlah total ikan (ekor) yang tertangkap pengaruh umpan yang berbeda pada alat tangkap Bubu Dasar dapat dilihat pada Tabel 1. berikut;

Tabel 1. Rataan Jumlah (ekor) Ikan

\begin{tabular}{l|c}
\hline \multicolumn{1}{c|}{ Perlakuan } & Rataan (ekor) \\
\hline Umpan Dedak Halus & $28,40 \mathrm{a}$ \\
Umpan Jagung & $11,60 \mathrm{~b}$ \\
Umpan Ubi & $16,20 \mathrm{~b}$
\end{tabular}

$$
\mathrm{KK}=24,68 \%
$$

Keterangan : Angka-angka yang di ikuti oleh huruf kecil yang berbeda pada kolom yang sama menunjukkan berbeda nyata menurut uji DNMRT pada taraf $5 \%$.

Tabel 1 menunjukan bahwa perlakuan berbagai jenis umpan berpengaruh nyata terhadap jumlah total (ekor) ikan yang tertangkap Bubu Dasar. Hasil penelitian menunjukan bahwa umpan dedak halus menghasilkan jumlah ikan yang terbanyak yaitu dengan rata-rata sebesar 28,4 ekor dan berbeda nyata dengan perlakuan umpan jagung dan umpan ubi, sedangkan jumlah ikan yang sedikit terdapat pada perlakuan umpan jagung yaitu rata-rata 11,6 ekor dan tidak berbeda nyata dengan perlakuan umpan ubi yaitu 16,2 ekor sehingga perlakuan dengan umpan dedak halus merupakan perlakuan terbaik terhadap rataan jumlah total ikan yang tertangkap Bubu Dasar di Sungai Tembesi. Hal ini diduga bau yang lebih menyengat dari dedak halus sehingga dapat mengundang ikan baik yang berada jauh maupun ikan yang ada diskeitar dari peletakan umpan tertarik oleh bau sehingga masuk ke dalam bubu. Baskoro (2012) juga menyatakan bahwa perbedaan jumlah hasil tangkapan disebabkan oleh jenis umpan yang berbeda, hal tersebut disebabkan karena bau yang dikeluarkan oleh kandungan kimia dari umpan tersebut.

Tingkah laku ikan terhadap alat tangkap berumpan dedak halus pada bubu dasar yang digunakan dalam penelitian ini, sangat dipengaruhi oleh umpan itu sendiri selama proses tertangkapnya ikan. Ketika ikan menyadari atau terangsang dengan kehadiran umpan, maka ikan akan berupaya mencari posisi sumber rangsangan dan ketika menemukan sumber rangsangan, ikan akan menyerang umpan; kemudian respon diakhiri dengan masuk ke bubu dan ikan tertangkap; atau menolak masuk ke bubu sehingga ikan tidak tertangkap. Stoner (2004) dalam Fitri (2011) menyatakan bahwa pada kebanyakan kasus, ikan akan tertarik umpan melalui isyarat kimia terlebih dahulu ketika umpan belum dapat dideteksi oleh organ penglihatan sehingga organ penciuman yang lebih dominan berperan. Dijelaskan oleh Rahardjo dkk. (2011) bahwa pelacakan makanan merupakan fungsi penghidu yang utama pada ikan yang makan dalam cahaya temaram atau mencari obyek yang dapat dimakan di antara material dasar dan tumbuhan.

Hasil penelitian juga menunjukan bahwa perlakuan umpan jagung merupakan perlakuan dengan jumlah ikan yang sedikit yaitu rata-rata sebesar 11,6 ekor dan tidak berbeda nyata dengan perlakuan umpan ubi yaitu 16,2 ekor hal ini diduga disebabkan warna yang ada pada kedua umpan hanya mampu mengundang ikan yang berada di sekitar peletakan umpan sedangkan ikan yang jauh dari peletakan umpan tidak dapat mendeteksi umpan tersebut karena indra penglihatan, sehingga memberikan pengaruh yang sama dalam merespons, dalam hal ini indra penglihatan ikan di Sungai Tembesi begitu jelas peranannya dalam membedakan warna dan bentuk umpan yang dicobakan. Selain itu juga kedua umpan yang dipasang mempunyai bentuk yang hampir sama. Sehingga umpan yang berwarna putih lebih disukai ikan dan menghasilkan jumlah ikan yang lebih banyak meskipun secara statistik dianggap sama. 
Penentuan jarak penglihatan selain dipengaruhi oleh kemampuan indera penglihatan ikan juga dipengaruhi oleh keadaan penglihatan dalam air. Pada kejernihan air yang baik dan terang, jarak penglihatan bergantung pada kemampuan penglihatan mata ikan itu sendiri. Pada jarak tertentu ikan dapat membedakan titik yang sangat berdekatan sebagai dua titik dan tidak sebagai satu titik atau kabur pengelihatannya. Menurut Gunarso (1985), pada kejernihan yang baik dan terang, maka jarak penglihatan untuk benda-benda yang kecil tergantung pada kemampuan jelasnya penglihatan mata, misalkan pada jarak di mana titik-titik yang letaknya bersekatan, dapat dibedakan sebagai dua titik dan tidak sebagai satu titik ataupun kabur kelihatannya. Dalam keadaan tertentu, beberapa jenis ikan yang berukuran besar mempunyai kemampuan untuk bisa melihat benda-benda yang agak besar dan berwarna kontras dengan latar belakangnya pada jarak beberapa puluh meter. Lebih lanjut Fujaya (2002) menyatakan bahwa perbedaan latar belakang dimensi penglihatan yang cukup baik untuk dapat dideteksi ikan, antara lain warna dan corak memungkinkan ikan dapat mendeteksi adanya perbedaan warna suatu obyek benda.

\section{Berat Total (gram) Ikan}

Hasil penelitian berat ikan (gram) yang tertangkap dengan Bubu Dasar di Sungai Tembesi dapat dilihat pada Tabel 2.

Tabel 2. Berat Total (gram) Ikan

\begin{tabular}{lcccc}
\hline \hline \multirow{2}{*}{ Perlakuan } & \multicolumn{3}{c}{ Berat Total Ikan (gram) } & Jumlah \\
\cline { 2 - 4 } & Stasiun I & $\begin{array}{c}\text { Stasiun } \\
\text { II }\end{array}$ & Stasiun III & $\begin{array}{c}\text { Total } \\
\text { (gram) }\end{array}$ \\
\hline Dedak Halus & 1.130 & 970 & 1.350 & 3.450 \\
Jagung & 339 & 550 & 460 & 1.349 \\
Ubi & 760 & 690 & 710 & 2.160 \\
\hline Jumlah & 2.229 & 2.210 & 2.520 & 6.959 \\
\hline \hline
\end{tabular}

Sumber : Hasil Penelitian 2017 - 2018

Berdasarkan Tabel 2. dapat dijelaskan bahwa hasil tangkapan Bubu Dasar yang dilakukan dengan mengunakan umpan yang berbeda pada setiap stasiun selama penelitian diperoleh hasil berat total (gram) ikan yaitu sebesar 6.959 gram dengan berat total ikan terbanyak terdapat pada umpan dedak halus yaitu sebanyak 3.450 gram, dan diikuti dengan umpan ubi yaitu sebesar 2.160 gram dan umpan jagung merupakan umpan dengan total berat ikan yang ringan yaitu sebesar 1.349.

Berat ikan yang tertangkap dengan menggunakan dedak halus lebih besar dibandingkan jagung dan ubi disebabkan karena rasangan yang diberikan oleh umpan berupa bau, warna, rasa dan bentuk salah satu kemungkinan adalah disebabkan oleh daya cium dan penglihatan ikan itu sediri. Kandungan kimia dedak halus yang menimbulkan bau yang menyengat, sehingga dapat menarik perhatian ikan untuk mendekat baik yang berada di sekitar umpan maupun ikan yang berada jauh dari peletakan umpan, sehingga ikan-ikan yang berukuran lebih besar dapat tertarik oleh bau dari umpan dan ikan yang tertangkap berukuran besar dan berat.

Menurut Syandri (1988) reaksi penciuman ikan disebabkan karena adanya bau yang larut dalam air. Penciuman ikan sangat sensitif terhadap bahan organik dan anorganik sehingga ikan dapat mengenali bau mangsanya (umpan). Lebih lanjut Carton dan Montgomery, (2003) dalam Fitri (2011) menyatakan bahwa bau yang diterima organ penciuman akan mengkondisikan rheotaxis ikan untuk melakukan suatu respons dengan cepat dan efisien terhadap sumber bau (makanan) tanpa melakukan penyeleksian terhadap informasi bau tersebut sebagai suatu isyarat yang kompleks. Zarochman (1994) menyatakan bahwa syarat-syarat umpan mati yang biasa digunakan alat tangkap pasif harus memiliki bau dan warna yang sesuai dengan ikan-ikan sasaran.

Untuk melihat pengaruh umpan berbeda terhadap jumlah total ikan yang tertangkap dilakukan analisis ragam anova dengan rancangan acak kelompok (RAK). Hasil anaslisis ragam menunjukan bahwa perlakuan umpan yang berbeda berpengaruh sangat nyata terhadap berat total ikan yang tertangkap Bubu Dasar $(\mathrm{P}<0,01)$. Untuk 
melihat umpan yang paling berpengaruh terhadap berat total ikan yang tertangkapa dilanjutkan dengan uji jarak Berganda Duncan Multipe Range Test (DMRT) pada taraf $5 \%$ (Steel and Torrie, 1994). Adapun rataan berat total ikan (gram) pengaruh umpan yang berbeda pada alat tangkap Bubu Dasar dapat dilihat pada Tabel 3. berikut;

Tabel 3. Rataan Berat (gram) Ikan

\begin{tabular}{l|c}
\hline \multicolumn{1}{c|}{ Perlakuan } & Rataan (gram) \\
\hline Umpan Dedak Halus & $690,00 \mathrm{a}$ \\
Umpan Jagung & $269,80 \mathrm{~b}$ \\
Umpan Ubi & $432,00 \mathrm{~b}$ \\
\hline
\end{tabular}

\begin{tabular}{cl}
\hline $\mathrm{KK}=25,16$ \\
\hline \hline Keterangan & $\begin{array}{l}\text { : Angka-angka yang di ikuti oleh huruf kecil yang } \\
\text { berbeda pada kolom yang sama menunjukkan } \\
\text { berbeda nyata menurut uji DNMRT pada taraf 5\%. }\end{array}$
\end{tabular}

Tabel 3 menunjukan bahwa perlakuan berbagai jenis umpan berpengaruh nyata terhadap berat ikan (gram) yang tertangkap bubu dasar di Sungai Tembesi. Hasil penelitian menunjukan bahwa umpan dedak halus menghasilkan berat ikan yang tertinggi yaitu sebesar 690 gram dan berbeda nyata dengan perlakuan umpan jagung dan umpan ubi, sedangkan berat ikan teringan terdapat pada perlakuan umpan jagung yaitu 269 gram dan tidak berbeda nyata dengan perlakuan umpan ubi yaitu 432 gram sehingga perlakuan dengan umpan dedak halus merupakan perlakuan terbaik terhadap rataan berat total ikan yang tertangkap Bubu Dasar di Sungai Tembesi. Hal ini diduga tingkah laku ikan terhadap aroma dan bau yang lebih tajam dan khas dari umpan dedak halus sehingga ikan tertarik mendekati dan memakan umpan serta tertangkap oleh bubu dasar. Hafrizal (1988) dalam Purbayanto dan Fitri (2007) juga mengatakan bahwa perbedaan jenis umpan dapat menyebabkan perbedaan hasil tangkapan, hal tersebut disebabkan karena bau yang dikeluarkan oleh kandungan kimia umpan tersebut.

Ahmad, Toehidi dan Efendi (1989), menjelaskan bahwa munculnya bau suatu bahan ditentukan oleh faktor komposisi dan struktur kimia dari bahan yang terkandung didalamnya. Kandungan lemak yang tinggi pada Dedak halus di duga dapat merangsang penciuman ikan untuk medekati umpan dan masuk kedalam bubu dasar, karena lemak yang tinggi akan menimbulkan bau yang menyengat dari umpan (Caprio, 1982 dalam Purbayanto dan Fitri, 2007). Hutabarat (1985) dalam Harsandi $d k k$, (2015) juga mengatakan bahwa kebiasaan makan dari ikan dapat dipengaruhi oleh bau dari makanan tersebut.

\section{B. Jenis-Jenis Ikan yang Tertangkap Bubu Dasar Pengaruh Umpan yang Berbeda}

Berdasarkan hasil penelitian yang telah dilakukan dengan menggunakan umpan dedak halus, jagung dan ubi pada alat tangkap bubu dasar maka diperoleh 3 jenis ikan yang tertangkap. Ke 3 jenis ikan tersebut merupakan ikan dari family Cyprinidae. Jika dibandingkan dengan Riki (2014), keanekaragaman di Sungai Tembesi terdapat 21 jenis dari 4 Ordo 7 Famili dan 13 Genus dari ikan yang berhasil di kumpulkan berjumlah 817 dengan menggunakan tiga Alat tangkap, yaitu: Jaring Insang (Gillnet), Jala Lempar (Filling gear), dan Tembak Ikan atau sering disebut Senapan Ikan. Sedangkan dalam penelitian ini hanyat terdapat 3 jenis ikan dari 2 ordo dan 1 family dan 3 genus dari 218 ekor yang berhasil dikumpulkan dengan alat tangkap yang digunakan hanya berupa bubu dasar. Untuk lebih rendah detilnya dapat dilihat pada gambar berikut :

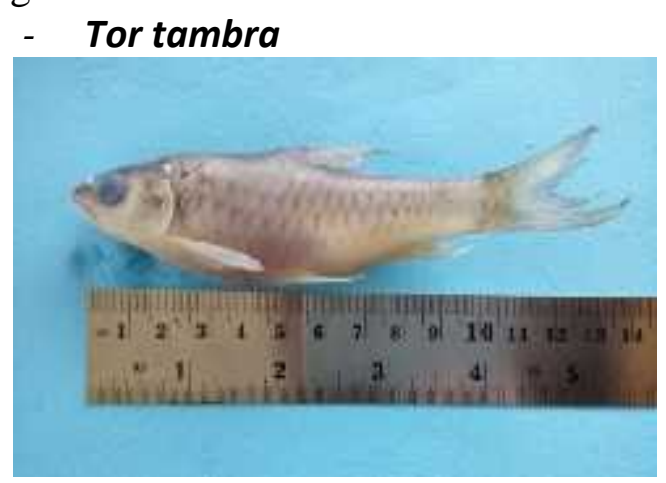

Gambar 2. Ikan Semah (Tor tambra) 
SEMAH : Journal Pengelolaan Sumberdaya Perairan

VOL. 2 No. 2

Desember 2018

\section{- Puntius binotatus}

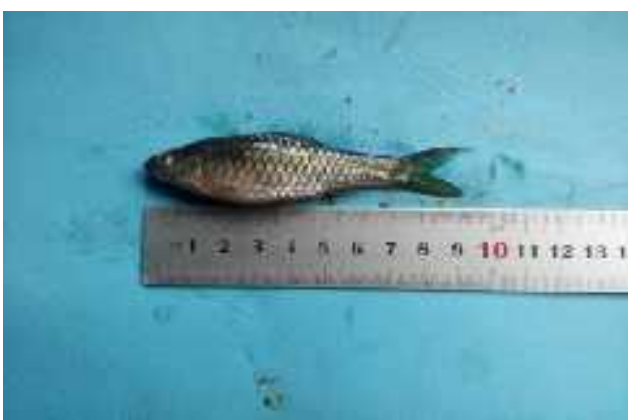

Gambar 3. Ikan Pareh (Puntius binotatus)

\section{- Rasbora elegans}

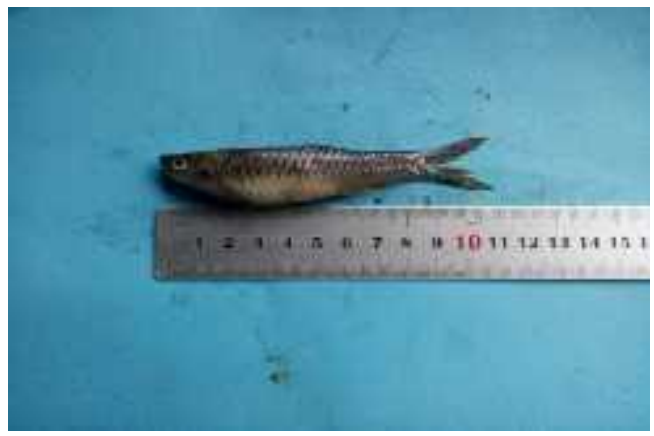

Gambar 4. Ikan Seluang (Rasbora elegans)

Hasil tangkapan bubu dasar pada penelitian ini adalah famili Cyprinidae. Famili Cyprinidae merupakan hasil tangkapan utama yang terdiri dari ikan semah (Tor tambra), ikan Pareh (Puntius binotatus), dan ikan Seluang (Rasbora elegans) dan ketiga jenis ikan ini ditemukan disetiap stasiun penelitian. Mayden et al. (2009) dalam Murni $d k k$ (2014) menyatakan bahwa famili Cyprinidae merupakan penghuni utama yang paling besar jumlah spesiesnya untuk beberapa sungai di dunia. Menurut Muchlisin $d k k$., (2003) ikan dari famili Cyprinidae ini dikenal sebagai kelompok terbesar ikan-ikan air tawar sejati.

Pada umumnya ikan dari family Cyprinidae yang tertangkap mempunyai bentuk tubuh torpedo agak memanjang dan pipih kesamping yang tertangkap pada semua jenis perlakuan umpan. Ikan ini diduga masuk ke dalam bubu karena tertarik oleh bau umpan karena ikan famili Cyprinidae mempunyai sungut yang sensitif dengan bau kimiawi. Hal
ojs.umb-bungo.ac.id/index-php/SEMAHJPSP

ISSN : 2580-0736

ini sesuai dengan pendapat kottelat, et al., (1993) yang menyatakan bahwa banyak anggota Cyprinidae memiliki sungut baik panjang atau pendek yang digunakan untuk mendeteksi makanan di dalam perairan yang keruh dan berarus deras.

Banyaknya ikan yang tertangkap di Sungai Tembesi dengan alat tangkap Bubu Dasar berdasarkan umpan yang digunakan selama penelitian akan disajikan pada Tabel 4.berikut :

Tabel 4. Hasil Tangkapan Bubu Dasar di Sungai Tembesi

\begin{tabular}{|c|c|c|c|c|}
\hline \multirow[b]{2}{*}{ Perlakuan } & \multicolumn{3}{|c|}{ Jenis Ikan } & \multirow{2}{*}{$\underset{\mathrm{h}}{\text { Jumla }}$} \\
\hline & $\begin{array}{c}\text { Sema } \\
\mathrm{h}\end{array}$ & $\begin{array}{c}\text { Pare } \\
\mathrm{h}\end{array}$ & $\begin{array}{c}\text { Seluan } \\
\mathrm{g}\end{array}$ & \\
\hline $\begin{array}{l}\text { Dedak } \\
\text { Halus }\end{array}$ & 106 & 8 & 28 & 142 \\
\hline Jagung & 51 & 3 & 4 & 58 \\
\hline Ubi & 61 & 5 & 15 & 81 \\
\hline Jumlah & 218 & 16 & 47 & 281 \\
\hline
\end{tabular}

Sumber : Hasil Penelitian 2017 - 2018

Berdasarkan Tabel 4. terlihat bahwa umpan dedak halus dapat memikat ikan putih atau ikan Semah dan tertangkap bubu dasar sebanyak 106 ekor, Pareh sebanyak 8 ekor dan ikan Seluang sebanyak 28 ekor, sedangkan umpan jagung dapat memikat ikan Semah dan tertangkap bubu dasar sebanyak merupakan 51 ekor, ikan Pareh sebanyak 3 ekor dan Seluang 4 ekor sedangkan umpan ubi dapat memikat ikan putih atau Semah dan tertangkap bubu dasar sebanyak 61 ekor semah, Pareh 5 ekor dan Seluang 15 ekor.

Berdasarkan hal tersebut di atas maka dapat disimpulkan bahwa umpan yang berbeda pada bubu dasar menangkap jenis ikan yang sama yaitu Semah (Tor tambra), Pareh (Puntius binotatus) dan Seluang (Rasbora elegans) namun jumlah ikan yang ditangkap berbeda tergantung karekteristik umpan itu sendiri. Sistem umpan memungkinkan hanya ikan yang menyukainya saja yang tertangkap (Purwanto A. A, dkk., 2013). Lebih lanjut Brandt (2005) menyatakan bahwa prinsip metode penangkapan dengan menggunakan 
SEMAH : Journal Pengelolaan Sumberdaya Perairan

VOL. 2 No. 2

Desember 2018

umpan adalah berusaha memikat ikan dengan sesuatu sebagai mangsanya yaitu berupa bau, rasa, gerakan, bentuk dan warna.

Dari Tabel 4 juga terlihat bahwa ikan Semah (Tor tambra) adalah ikan yang paling banyak tertangkap pada setiap umpan yang diuji pada Bubu Dasar di Sungai Tembesi. Hal ini karena ikan semah atau ikan tambra bersifat pemakan segala atau omnivora (Sulastri dkk. (1985) dalam Haryono (2006). Hal yang sama juga dinyatakan Rupawan $d k k$, (1999) dalam Subagja dkk, (2009) bahwa ikan semah (T. douronensis) di Danau Kerinci dan Sungai Merangin-Jambi bersifat omnivous dengan makanan utamanya berupa buahbuahan $(38,5 \%)$, moluska $(29,7 \%)$, detritus $(16,9 \%)$, dan serangga air $(12,7 \%)$.

Banyaknya ikan Semah (Tor tambra) yang tertangkap di Sungai Tembesi sehingga dapat dinyatakan bahwa Sungai Tembesi adalah habitatnya ikan Semah. Ross (1997), bahwa keanekaragaman dan kelimpahan ikan juga ditentukan oleh karakteristik habitat perairan. Karakteristik habitat di sungai sangat dipengaruhi oleh kecepatan aliran sungai. Kecepatan aliran tersebut ditentukan oleh perbedaan kemiringan sungai, keberadaan hutan atau tumbuhan di sepanjang daerah aliran sungai yang akan berasosiasi dengan keberadaan hewan-hewan penghuninya. Lebih lanjut Siagian (2009) menyatakan bahwa faktor habitat seperti fisik, dan kimia serta ketersediaan sumber makanan bagi organisme ikan sangat mempengaruhi keberadaan ikan dan dapat mempengaruhi distribusinya di habitat itu. Menurut Subagja $d k k$, (2009) Habitat ikan Semah adalah perairan yang mengalir dengan substrat dasar perairan berbatu atau berkerikil. Anakan ikan ditemukan di perairan yang dangkal dan ikan dewasa ditemukan di cekungan sungai yang dalam (lubuk).

\section{KESIMPULAN DAN SARAN}

\section{Kesimpulan}

ojs.umb-bungo.ac.id/index-php/SEMAHJPSP

ISSN : 2580-0736

Berdasarkan penelitian yang telah dilakukan maka dapat ditarik beberapa kesimpulan sebagai berikut :

1. Jenis umpan berbeda berpengaruh sangat nyata terhadap jumlah total ikan (ekor) dan berat total (gram) ikan yang tertangkap bubu dasar di Sungai Tembesi Kabupaten Merangin ( $\mathrm{F}$ hitung > $\mathrm{F}$ tabel) dengan jumlah ikan yang tertangkap sebanyak 281ekor dengan berat total 6.959 gram.

2. Dedak halus merupakan umpan yang disukai ikan yang tertangkap dengan menggunakanan alat tangkap bubu dasar di Sungai Tembesi Kabupaten Merangin.

3. Hasil tangkapan menggunakan bubu dengan umpan yang berbeda menghasilkan sebanyak 3 jenis ikan yaitu Semah, Pareh dan Seluang.

\section{Saran}

Berdasarkan penelitian yang dilakukan maka disarankan bagi nelayan yang mengoperasikan bubu dasar di Sungai Tembesi untuk menggunakan umpan dedak halus. Dan disarankan untuk melakukan penelitian lebih lanjut tentang umpan jenis lain dan ekosistem perairan di Sungai Tembesi.

\section{DAFTAR PUSTAKA}

Ahmad, S. A, A. Toehidi dan S. Efendi. 1989. Kimia Organik. Angkasa, Bandung

Baskoro. S. 2012. Efektivitas Umpan Buatan Dalam Penangkapan Ikan Karang Konsumsi Pada Bubu Di Kepulauan Seribu. Skripsi. Fakultas Perikanan Dan Ilmu Kelautan. Institut Pertanian Bogor. Bogor

BPS Kabupaten Merangin, 2015. Merangin dalam Angka 2015

Brandt. AV. 2005. Fish Catching Methods of the Word 4 Edition. England: Fishing News Book Ltd

Budiyono, 2011. Studi Hubungan Kualitas Air Dengan Keanekaragaman Jenis Ikan 
SEMAH : Journal Pengelolaan Sumberdaya Perairan

VOL. 2 No. 2

Desember 2018

Di Sungai Batang Bungo Kabupaten Bungo.

Http://budibungo.blogspot.com/2010/ 06/keaneka-ragaman-jenis-ikan-disungai.html. diunduh Januari 2017

Fitri, A. 2011. Respons Makan Ikan Kerapu Macan (Ephinephelus fuscoguttatus) Terhadap Perbedaan Jenis dan Lama Waktu Perendaman Umpan Jurnal Ilmu Kelautan Vol 16 (3) : 159 164. Di Unduh 15 April 2018

Fujaya, Y. 2002. Fisiologi Ikan. Dasar Pengembangan Teknologi Perikanan. Fakultas Ilmu Kelautan dan Perikanan Universitas Hasanuddin.

Gunarso W. 1985. Tingkah Laku Ikan dalam Hubungannya dengan Alat, Metode, dan Teknik Penangkapan. Bogor: IPB Press.

Harsandi, A, A. Brown dan I. Syofyan. Pengaruh Variasi Komponen Biji Sawit Terhadap Hasil Tangkapan Ikan Sepat Rawa (Trichogaster trichopterus) Pada Alat Tangkap Bubu. Jurnal Fakultas Perikanan Universitas Riau. Pekanbaru.

Haryono. 2009. Aspek Biologi Ikan Tambra (Tor tambroides Blkr.) yang Eksotik dan Langka sebagai Dasar Domestikasi. Jurnal Biodiversitas. Volume 7, Nomor 2. April 2006. ISSN: 1412-033X. Halaman: 195-198. Diunduh 10 September 2018

Kottelat M, Anthony J. W, Sri Nurani K \& Soetikno W. 1993. Freshwater Fishes Of Western Indonesia And Sulawesi. Jakarta : Periplus Editios (Hk)

Muchlisin, Z.A., A.Siti, K.H. Khoo, and R. Edi. 2003. Keanekaragaman Ikan Air Tawar Di Nanggroe Aceh Darussalam (NAD), Indonesia. (PhD Thesis). Universiti Sains Malaysia, Penang.
ojs.umb-bungo.ac.id/index-php/SEMAHJPSP

ISSN : 2580-0736

Murni, Y.M, Dahelmi dan D.I. Roesma. 2014. Inventarisasi Jenis-Jenis Ikan Cyprinidae di Sungai Batang Nareh, Kabupaten Padang Pariaman.

Purbayanto. A dan Fitri. A.D. P. Pengaruh Perbedaan Umpan Terhadap Pola Tingkah Laku Makan Ikan Kerapu Macan (Ephinephelus fuscoguttatus). Jurnal Ilmu-ilmu Perairan dan Perikanan Indonesia, Juni 2009, Jilid 16, Nomor 1: 25-31. Diunduh 15 April 2018

Rahardjo, M.F., Sjafei, D.J., Affandi, R., \& Sulistiono. 2011. Iktiology. Lubuk Agung, Bandung

Ross, R., 1997. Fisheries Conservation and Management. USA: Prentice Hall, Inc.

Sari, E.A, Bustari dan Usman. 2016. Pengaruh Umpan Terhadap Hasil Tangkapan Bubu Dasar Di Sungai Kampar Kanan Desa Salo Kecamatan Salo Kabupaten Kampar Provinsi Riau. Jurnal online Mahasiswa Fakultas Perikanan dan Ilmu Kelautan. vol 4 No. 2. http://jom.unri.ac.id/index.php/ JOMFAPERIKA/article/view/16107/0. Diunduh 15 April 2018

Steel, R, G, D dan Torrie, J, H. 1994. Prinsip dan Prosedur Statistika Suatu Pendekatan Biometrik. Penerbit PT. Gramedia Pustaka Utama, Jakarta

Subagja \& Marson. 2008. Identifikasi Dan Habitat Ikan Semah (Tor Sp.) Di Sungai Lematang, Sumatera Selatan. Jurnal Bawal: Vol.2 No.3-Desember 2008: 113 - 116. Diunduh 10 September 2018

Subagja, Wibowo. A dan Marson. 2009. Pertumbuhan Ikan Semah (Tor tambra, Valenciennes, 1842) Di Perairan Sungai Musi, Sumatera Selatan. Jurnal Bawal : 
Vol.2 No.4-April 2009: 133-138. Diunduh 10 September 2018

Subani W dan Barus HR. 1989. Alat Penangkapan Ikan dan Udang Laut di Indonesia. Edisi Khusus. Jurnal Penelitian Perikanan Laut. Jakarta: Balai Penelitian Perikanan Laut. Badan Penelitian dan Pengembangan Pertanian. Jakarta.

Sukmono. T dan M. Margaretha. 2017. Ikan Air Tawar di Ekosistem Bukit Tigapuluh. Yayasan Konservasi Ekosistem Hutan Sumatera dan Frankfurt Zooloogical Society.

Syandri, H. 1988. Tingkah Laku Ikan. Fakultas Perikanan Unversitas Bung Hatta. Padang. 63 hal.

Watem. T.M, H.J. Kumajas dan F. Silooy. 2015. Pengaruh penambahan ekstrak minyak tenggiri pada umpan bubu terhadap hasil tangkapan ranjungan di perairan Malalayang, Kota Manado. Jurnal Ilmu dan Teknologi Perikanan Tangkap 2(1): 23-27.

Zarochman. 1994. Suatu Pengenalan Teknik Penangkapan Crab dengan Bubu Berangkai di Jepang. Media Informasi Pemanfaatan Sumberdaya Hayati Laut. Departemen Kelautan dan Perikanan. Balai Pengembangan Penangkapan Ikan. Semarang. Jurnal Arrioma. I (1) : 1-12 